\title{
Effect of Size and Density of Population of Laboratory Mice on the Parameters Determining Their Production ${ }^{1}$
}

\author{
Krystyna ADAMCZYK
}

Adamczyk K., 1977: Effect of size and density of population of laboratory mice on the parameters determining their production. Acta theriol. 22, 32: 459-484 [With 4 Tables \& 5 Figs.].

Examination was made of the effect of the number and density of adult individuals (basic stock) on production of populations of laboratory mice (Mus musculus Linnaeus, 1758) and of the parameters defining it. Sixty-eight populations were set up, arranging the initial number of individuals in the basic stock and their density in a gradient. The initial number of mice in a population was maintained for 5 months at a constant level by removing the surplus young individuals of $4-6$ weeks of age. Two groups of populations were distinguished those a small (from 2 to 20 mice) or large (from 40 to 220 mice) size of the basic stock. In the first group of populations both the factors examined were found to affect population parameters. Production increased with an increase in the size of the population despite the inhibiting effect of density, the increase being due chiefly to an increase in biomass of born animals. An increase density reduced the number of animals born by reducing frequency of gestation and increasing cannibalism. Both population size and density lowered the survival rate of young animals. Biomass production removed during the experiments increased with an increase in population size, reaching a maximum in the group of 20 individuals. In the second group of populations, population size exerted a significant effect on the parameters examined. Production increased with an increase in population size owing to the increase in biomass of born animals. Cannibalism also increased. Survival of young mice and biomass production removed did not change with an increase in size and density of the basic stock. The paper contains a discussion of the effect of the number of animals in a population, density and area occupied on population processes.

[Inst. Ecol., Polish Acad. Sci., 05-150 Dziekanów Leśny, Poland].

\section{INTRODUCTION}

A number of researchers have shown that population density influences a wide variety of characteristics of the individuals in the population. The results of these studies have been summarized by Alle e et al. (1949), but not all aspects of this problem have been fully explained. Later studies in the fields of animal husbandry ( $\mathrm{H}$ a nsen \& $\mathrm{Backer}$, 1960; Knap \& Kaspar, 1969; Mazanowski, 1972 and others),

1 Praca została wykonana w ramach problemu węzłowego 09.1.7, koordynowanego przez Instytut Ekologii PAN. 
pond fisheries (Wolny, 1962; Backiel \& LeCren, 1967) and hunting ( $\mathrm{k}$ o $\mathrm{m} \mathrm{nicki}, 1972$ and others) have been particularly important from a practical standpoint. All of these studies attempted to identify an optimum population density at which the maximum amount of useful production could be sustained. Few studies however have been made on the effect of population size on the attributes of animals. Population size may be a factor as important as density. Attention has been drawn to this by Petrusewicz (1963) in his review of the results of studies on the relationship between habitat size and population size.

The purpose of the present study was to ascertain whether an influence is exerted and if so in what way, by population size (measured by the total number of individuals), population density (measured by the number of individuals $/ \mathrm{m}^{2}$ ), and both these factors jointly on production and the parameters defining it (survival, natality and individual growth).

The studies were made on populations of white mice (Mus musculus Linnaeus, 1758), treating them as an appropriate model of the phenomena taking place in populations of captive animals.

This paper is one of the stages of research on ecological phenomena conditioning a high degree of production in animal populations kept within a small area. In addition to the effect of size and density, the studies were also aimed at defining the effect of age and sex structures of the population on production.

\section{METHODS: EXPERIMENTAL}

Two experiments were conducted: (1) A different number of adult individuals $(2,10,20,40,60,80,100,220)$ were placed in wooden cages of uniform area $\left(0.64 \mathrm{~m}^{2}\right)$. Gradients were thereby established of population sizes ranging from 2 to 220 individuals and of density ranging from 3 to 344 animals $/ \mathrm{m}^{2}$. This experiment was replicated three times (at three different times, with a total of 31 populations (Table 1). (2) This experiment was carried out in four series, which differed from each other with respect to density. The densities were chosen on the basis of changes in production in the first experiment: $31,94,156,344$ individuals $/ \mathrm{m}^{2}$. A uniform gradient of number of mice from 2 to 220 individuals was maintained in each series. In order to maintain uniform density within each series the size of the cage was increased in proportion to the number of animals. Populations belonging to one series were reared simultaneously. A total of 37 populations was examined in all the series of this experiment (Table 1).

The mice used for the studies were obtained from a stock maintained for more then 10 years by the Institute of Ecology of the Polish Academy of Sciences which originated from four pairs of parents which were siblings.

The populations were set up using mice 2-4 months old, individually marked by toe-clipping. Sex ratio was $1: 1$. Animals more than 6 weeks old, that is, potentially capable of reproduction, were termed the basic stock of the population. 
Individuals of the basic stock were counted and weighed individually every two weeks, examining each animal carefully and recording changes in the skin. The reproductive condition of females was evaluated on the basis of their extermal appearance, difference in body weights between successive weighings and such indicators as a copulation plug or blood in the vagina. With the frequency of inspection of females the number of pregnancies detected was underestimated by $18.7 \%$ based on all gestations (A d a mczyk \& $\mathrm{Wa} l \mathrm{kowa}, 1974$ ). By multiplying the number of pregnancies detected by our inspections by the appropriate correction factor, we obtained the number of all pregnancies for the study period. After each series of experiments was completed the females were dissected to estimate the number of young per litter.

Table 1

Number of populations in different series of experiments for defined size and density of population. Number of a series is given in parentheses.

\begin{tabular}{|c|c|c|c|c|c|c|c|c|c|}
\hline \multicolumn{10}{|c|}{ Experiment I } \\
\hline Population size & 2 & 10 & 20 & 40 & 60 & 80 & 100 & 220 & Total \\
\hline Density, mice $/ \mathrm{m}^{2}$ & 3 & 16 & 31 & 62 & 94 & 125 & 156 & 344 & \\
\hline June 22,1970 (I) & 3 & 1 & 1 & 1 & 1 & 1 & 1 & 1 & 10 \\
\hline Sept. 7,1970 (II) & 3 & 1 & 1 & 1 & 1 & 1 & 1 & 1 & 10 \\
\hline Febr. 8, 1971 (III) & 3 & 1 & 1 & 1 & 1 & 1 & 2 & 1 & 11 \\
\hline \multicolumn{10}{|c|}{ Experiment II } \\
\hline Population size & 2 & 20 & & & 100 & 150 & & 220 & Total \\
\hline Jan. 31,1972 (I) $31^{*}$ & 2 & 1 & & 1 & 1 & 1 & & - & 6 \\
\hline Sept. 21,1971 (II) $94^{*}$ & 7 & 1 & & 1 & 1 & 1 & & - & 11 \\
\hline March 20,1972 (III) $156^{*}$ & 5 & 1 & & $i$ & 1 & 1 & & 1 & 10 \\
\hline Oct. 16,1971 (IV) $344^{*}$ & 5 & 1 & & 1 & 1 & 1 & & 1 & 10 \\
\hline
\end{tabular}

* Number indicating the density of mice per $\mathrm{m}^{2}$.

A considerable number of the born mice were observed to be eaten within a few hours after birth by both males and females of the basic stock, and consequently the number of born mice in the population was estimated indirectly, multiplying the number of gestations ending in birth during the course of the experiments by the average litter size (A damczy k \& $\mathrm{Walkowa}, 1974$ ).

The cages were inspected daily, recording the number of born mice and their combined weight (only for live individuals). Newborn mice born of different days were marked on the body by a system of coloured stains (Pigmentum Castelani stain). Twice a week a count was made of the numbers of mice born on consecutive days that had survived to the count day. Mice of the same age were weighed as a group during the first four weeks of life.

During the experiment the initial size of the basic stock was maintained as far as possible, preventing its increase by removing young individuals at $4-6$ weeks of age from the population. In the event of a drop in the number of mice in the basic stock due to mortality, an appropriate number of young animals were left in the population. The size of the basic stock decreased only in those populations in which young individuals lived for less than 4 weeks (Table 2). Thus the basic stock included mice with which the populations had been established and also young individuals which had reached the age of $4-6$ weeks anc had not been removed from the population. 
Table 2

Comparison of numbers in basic stock at beginning and end of the experiment.

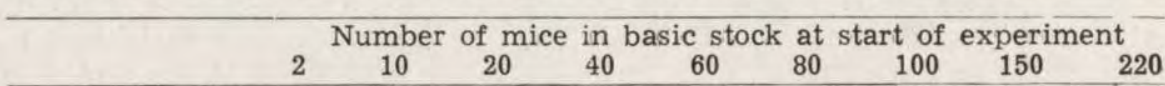

Experiment I

\begin{tabular}{lrrrrrrrrr} 
Series I & 2 & 10 & 20 & 34 & 57 & 68 & 100 & - & 185 \\
Series II & 2 & 10 & 19 & 39 & 52 & 67 & 100 & - & 193 \\
Series III & 2 & 8 & 18 & 40 & 52 & 65 & 100 & - & 220 \\
$\quad$ Experiment II & & & & & & & & & \\
Series I & 2 & - & 18 & - & 39 & - & 86 & 130 & 178 \\
Series II & 2 & - & 19 & - & 56 & - & 65 & 84 & 111 \\
Series III & 2 & - & 18 & - & 48 & - & 58 & 130 & - \\
Series IV & 2 & - & 20 & - & 60 & - & 67 & 100 & - \\
\hline
\end{tabular}

Food (granulated LMS mixture) and water were supplied ad libitum, and in addition milk and sprouted wheat were given twice a week. The food was accessible to all individuals in the population. Sawdust was used as litter, and it was changed when it became dirty.

The duration of a series of experiments was 5 months. Each series started at a different time (Table 1) in order to eliminate any possible influence of the season.

The numbers of born animals, individuals removed from the population and supplementing losses in the basic stock in the different series of the two experiments, are given in Table 3.

Table 3

Number of mice born, removed from the population and supplementing losses in the basic stock.

\begin{tabular}{|c|c|c|c|c|c|c|}
\hline \multirow[b]{2}{*}{ Series } & \multicolumn{3}{|c|}{ Experiment I } & \multicolumn{3}{|c|}{ Experiment II } \\
\hline & Born & Removed & $\begin{array}{l}\text { Supple- } \\
\text { menting }\end{array}$ & Born & Removed & $\begin{array}{l}\text { Supple- } \\
\text { menting }\end{array}$ \\
\hline I & 8863 & 520 & 38 & 8120 & 37 & 9 \\
\hline II & 8818 & 277 & 23 & 7213 & 167 & 12 \\
\hline III & 9975 & 526 & 71 & 5622 & 68 & 1 \\
\hline IV & - & - & - & 4618 & 142 & 33 \\
\hline Total & 27656 & 1323 & 132 & 25573 & 414 & 55 \\
\hline
\end{tabular}

\section{METHODS: ANALYTICAL}

Linear multiple regression was used for analysis of the material, which made it possible to simultaneously examine the relationship between various population parameters $(Y)$ and the two factors, population size $\left(X_{1}\right)$ and density $\left(X_{2}\right)$. A relationship of this type is illustrated by the following regression equation:

$$
\mathrm{Y}=b_{0}+b_{1} X_{1}+b_{2} X_{2}
$$

Values of the coefficients $b_{0}, b_{1}, b_{2}$ were calculated on the basis of empirical data, by means of the equations presented by Eland (1964). 
The coefficient of multiple correlation $\left(R^{2}\right)$ is the measure of the relationship between the population parameter $(Y)$ and the joint effect of the factors examined $\left(X_{1}, X_{2}\right)$. This coefficient permits the estimation of the significance of the effect of these two factors $(P<0.05$ considered significant) on the population parameter. In order to ascertain the effect of each factor separately the coefficients of partial correlation was calculated. The first of these is the measure of the linear relationship of the population parameter and the size of the basic stock with an established density, and the second the measure of the relationship between density, with a constant size of stock, and the population parameter.

The study populations were divided into two groups, differing from each with respect to the size of the basic stock: small (from 2 to 20 individuals) and large (from 40 to 220 individuals). This division was based on the value of the biomass of mice taken from the populations, which increased with increase in size of the basic stock up to 20 mice and was distinctly lower above this size. This biomass was inter alia the result of the survival of individuals in the basic stock, their reproduction and the survival of young mice. The effect exerted by size and density of the basic stock on these population indices were examined for each group. Analysis was also made for all populations together.

Coefficients of multiple correlation and coefficients of partial correlation for the two groups of population are presented in Table 4. A relationship between a population parameter and one or both of the two factors (population size and/or density) is presented only in cases where the regression differs significantly from zero $(P<0.05)$.

When analyzing the survival of individuals in the basic stock it was necessary (on account of the insufficiently large number of animals) to combine those population in which the basic stock comprised a pair of mice, in one group.

\section{SURVIVAL OF BASIC STOCK}

Two groups of mice were distinguished in the stock: individuals remaining in the population throughout the entire study period were allocated to the first of these groups, and those animals which were born in the population and were not removed from it, but replaced mice from the first group which died to the second group.

A check was made for the first group of mice in the basic stock to see whether the number of animals in the stock and their density affects their survival. The percentage of group one mice surviving to the end of the experiment was taken the survival rate. Survival rates for males and females were calculated separately.

In populations consisting of both a small and a large number of individuals in the basic stock, the factors examined were not found to affect the survival rate of males (value of the coefficient of multiple correlation $R^{2}$ is not significant-Table 4, row 1 ). On the other hand the analysis of all populations jointly showed that both factors acting jointly exert a significant effect of survivorship of males. In order in show which of the factors, affects the survival rate of males coef- 


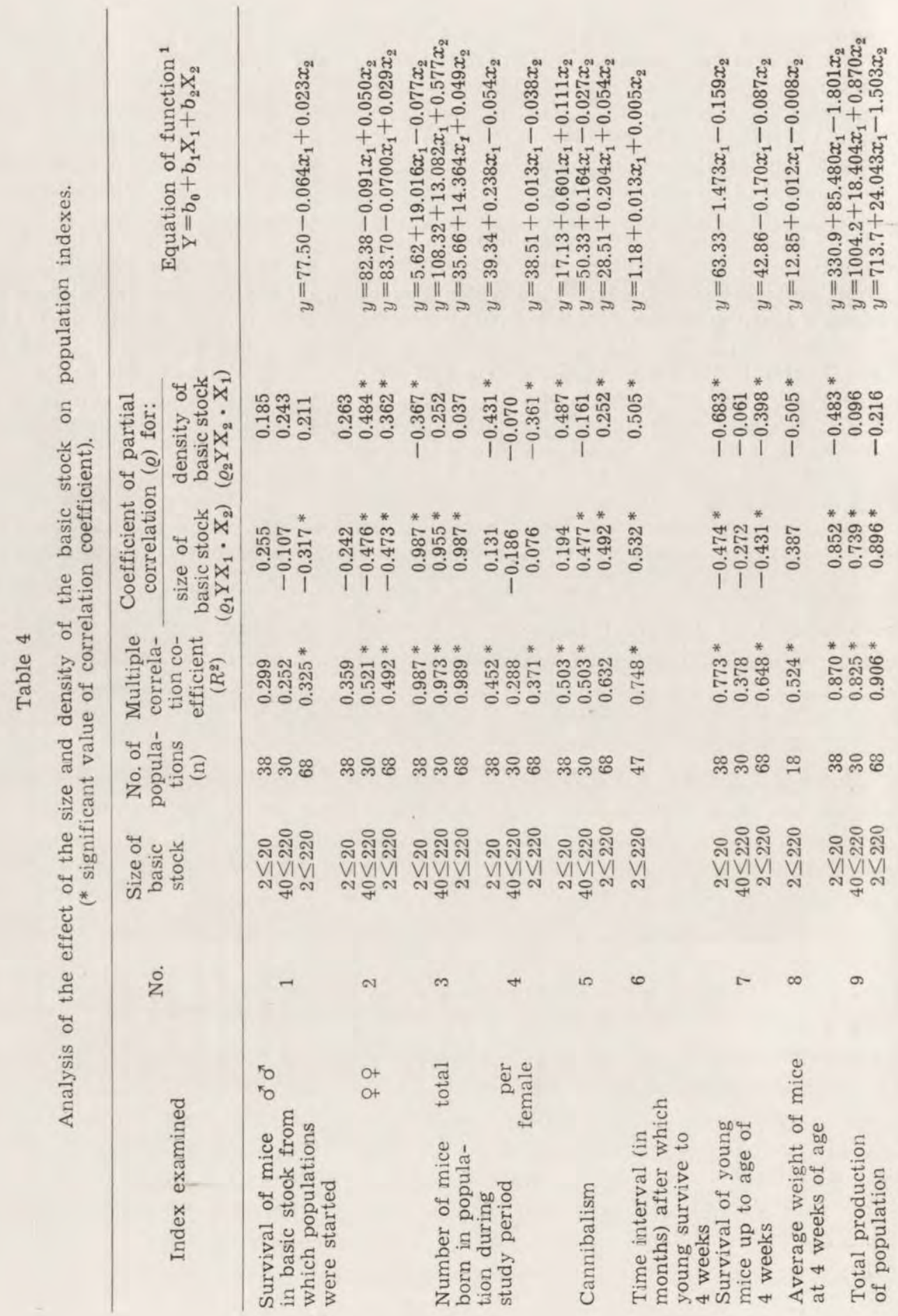




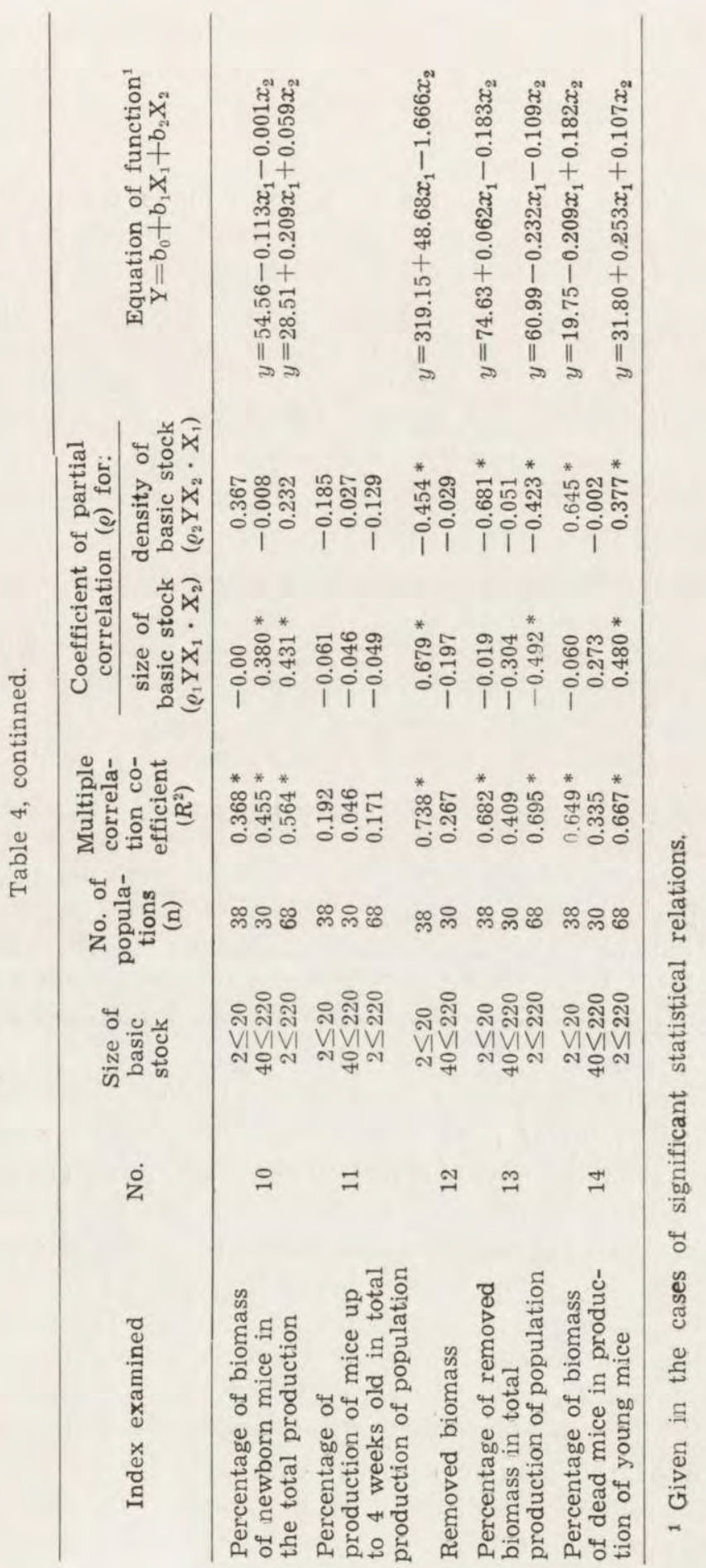


ficients of partial correlation $\left(\varrho_{1}, \varrho_{2}\right)$ were calculated. It was found that an increase in the number of individuals in the basic stock reduces survival of male, whereas increase in density is not of significant importance (Table 4 row 1 ).

Analysis of the survival rate of females made for populations with a small basic stock showed that the number of animals and their density did not significantly affect female survivorship, but in populations with a large basic stock female survivorship was affected (Table 4, row 2). An increase in the size of the basic stock reduced the survival rate of females, while an increase in density increased it. Populations with large basic stocks influenced the results of analyses obtained for all populations together consequently the relationship between female survivorship and the factors examined is the same for populations with large basic stocks as for all populations (Table 4 , row 2).

Thus the survival rate for males and females of the basic stock decreased with an increase in the number of animals, but only in the large populations. The survival rate of females increased with increasing density in these populations, while in populations with small basic stocks survival rate was unaffected by population size or density.

The survival rate of adult individuals included in the basic stock may differ in different periods of the population's life. To check this, the surival rates of males and females at two-weekly intervals (percentage of mice surviving in one period of time in relation to the preceding period) were examined. This rate could be calculated only for populations in which the number of animals studied was sufficiently large (above 10 mice). Survival rates were not altered in any particular direction in the different populations with an increase in the length of the population's life, but fluctuated between periods (for males from $90 \%$ to $100 \%$ and for females from $95 \%$ to $100 \%$ ).

The second group of mice in the basic stock was far less numerous than the first and consisted of younger animals. These individuals replaced mice that died in the first group at different times from the beginning of the experiment (after 2.5 months at the earliest). Hence mice of this group spent different lengths of time in the population. In order to compare their survivorship with survivorship of the first group survival rates for two-weeks intervals were calculated. Survival rates were $98.5 \%$ for the first group of mice and $97.7 \%$ for the second. The statistically non-significant difference between those percentages is evidence of the similar survival rate of mice in the two groups. In neither group were differences in survival of males or females statistically significant. 
The unfavourable influence which increase in population size and density exerted on different individuals may be manifested in a reduction in their resistance, as shown by the poor state of health observed in some animals. In the two series of the second experiment, which differed in density ( 31 and 156 individuals $/ \mathrm{m}^{2}$ ), a purulent infection was observed on the skin in the larger populations. Abscesses were found only on those individuals of the basic stock which had remained in the population from the start of the experiment. The percentage of infected males and females in relation to the current number of individuals of the given sex in the basic stock was calculated for the different populations and values obtained were compared by means of the Student's $t$ test. Infection rate was significantly higher $(0.02<P<0.01)$ for males in all populations than for females (Fig. 1). It did not differ in any

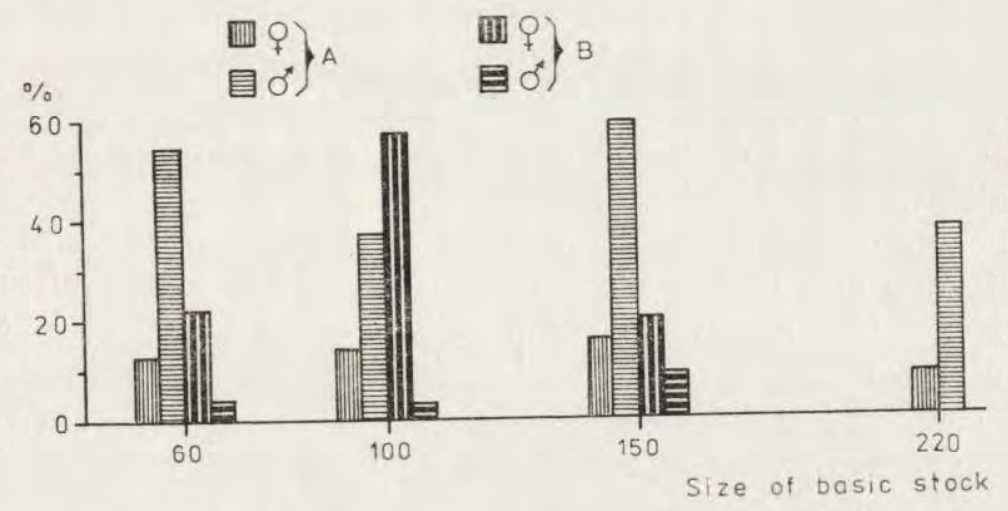

Fig. 1. Percentage of infected males and females of the basic stock, with different density of mice. A $-156 / \mathrm{m}^{2}, \mathrm{~B}-31 / \mathrm{m}^{2}$.

given direction with increase in the size of the basic stock. In order to compare the number of infected individuals between the two densities, the percentages of infected animals at the different densities were calculated and the values obtained compared by means of the $t$ test. It was found that fivefold increase in density increased the percentage of infected individuals from $17.4 \%$ to $28.5 \%$ (males from $31.9 \%$ to $44.9 \%$ and females from $8.0 \%$ to $14.2 \%$ ). These differences are statistically significant $(0.02<P<0.01)$.

\section{REPRODUCTION}

Analyses were made to ascertain whether increase in size and/or density of the basic stock affects the number of mice born. An affect was observed in both groups of populations and for the material as 
a whole (Table 4, row 3). When each factor was analyzed separately the following relationships were found: in small populations the number of mice born increased with an increase in the number of animals in the basic stock and decreased with an increase in density. In large populations the number of mice born also increased with an increase in the number of mice in the basic stock, but increase in density did not exert any significant effect. In the analysis of all populations together it was found that the number of mice born increased with an increase in size of the basic stock, but increase in density was not of great significance.

The number of mice born in a population is determined by the number of females capable of reproducing, the frequency of their gestations, and the average litter size. An estimate of the number of females participating in reproduction was made for mice remaining in a population for at least one month from the start of the experiment. The numbers obtained for the different populations show that almost all females were pregnant at least once during the study period. Nongestating females constituted only $0.2 \%$ of all females in all of the populations.

It has been shown that for these populations litter size did not exhibit variations in any particular direction due to the effect of the factors examined and was $7.5 \pm 0.2$ individual (A d a mczy k \& W a lk o w a, 1974).

The frequency of gestations were determined on the basis of variations in the average number of young produced per female during the study period. The effect of changes in size and density of the basic stock of frequency of gestation was examined. In a small populations an increase in density reduced the average number of mice produced per female, whereas an increase in population size had no significant effect (Table 4, row 4). In large populations neither factor had a significant affect. In the analysis of all populations together the same relationship was observed as in the small populations.

Thus reduction in the number of mice produced per female, due to an increase in density in small populations is caused by a lower frequency of gestations, since neither the number of females participating in reproduction nor the average litter size changed significantly due to the effect of changes in the factors studied.

\section{JUVENILE SURVIVAL}

In the study populations a considerable number of newborn mice were eaten by members of the basic stock within 24 hours from the 
time of birth (Adamczyk \& Walkowa, 1974). The percentage of newborn mice eaten prior to their initial registration in the total number of mice born in a population was used as an index of cannibalism. In populations with a small basic stock the maximum value of this index was $53 \%$, and the minimum $0 \%$, but in populations with a large basic stock the corresponding figures were $85 \%$ and $17 \%$ respectively. The effects of population size and density on changes in this phenomenon were examined. Cannibalism increased with an increase in density in small populations, while an increase in the number of animals was not of significant importance (Table 4 row 5). In large populations, however, cannibalism intensified with an increase in population size but increases in density had no significant influence on a variation in this phenomenon. The results obtained by the analysis made for all populations together are affected by the relationships discovered for each group separately, and hence cannibalism intensified with an increase in both population size and density (Table 4, row 5).

In populations with small basic stocks part of the mice born during the first month of the experimental period survived up to the age of $4-6$ weeks, whereas in large populations all the young animals died before reaching this age. The length of time interval (in months) between the start of experiment and the time at which at least one of the newborn mice had reached the age of $4-6$ weeks was calculated for the experimental populations. The effect of size and density of the basic stock on the length of this period was examined for all populations together. It was found that an increase in both factors caused prolongation of the period (Table 4, row 6 ).

The survival of mice up to the age of $4-6$ weeks was examined for succesive months of the experimental period. For this purpose the percentage of animals of $4-6$ weeks old was calculated for successive months from the total number of the newborn mice recorded in daily inspections. Calculation of the number of newborn mice in each month on the basis of the number of gestations and average litter size presented difficulties connected with establishing the date of birth. The survival rates calculated for populations with uniform size of basic stock in successive months exhibited considerable variation (Fig. 2). In small populations survival of young mice is distinctly better than in large populations.

The survival of young mice for the whole study period was also analyzed by calculating the survival rates for each population as the percentage of mice surviving up to the first, second etc. week of life from the total number of mice born. Calculation was made of the 


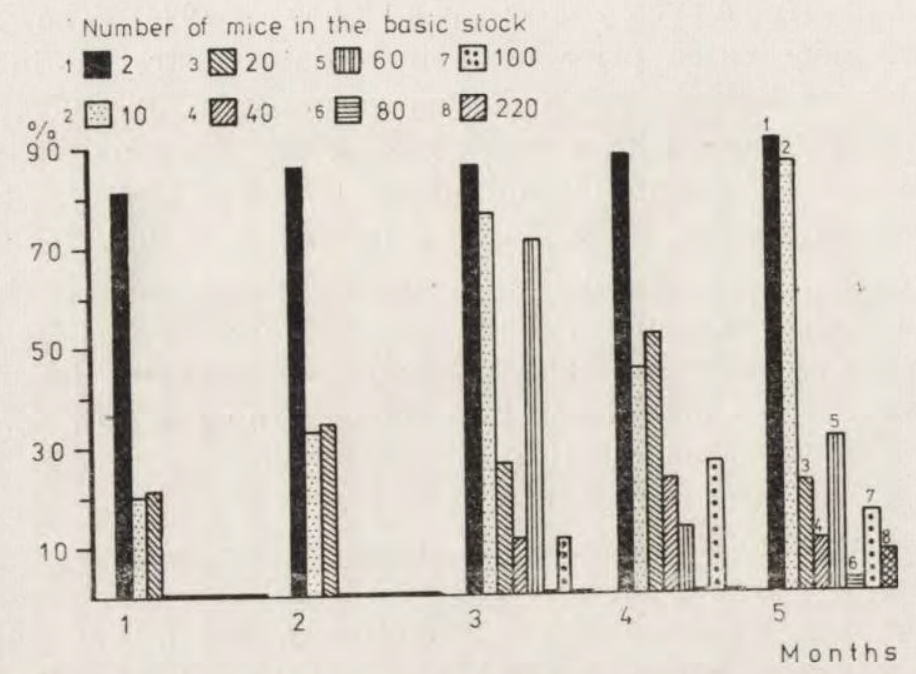

Fig. 2. Survival rates of young mice calculated for populations with uniform size of basic stock in successive months of the experimental period.

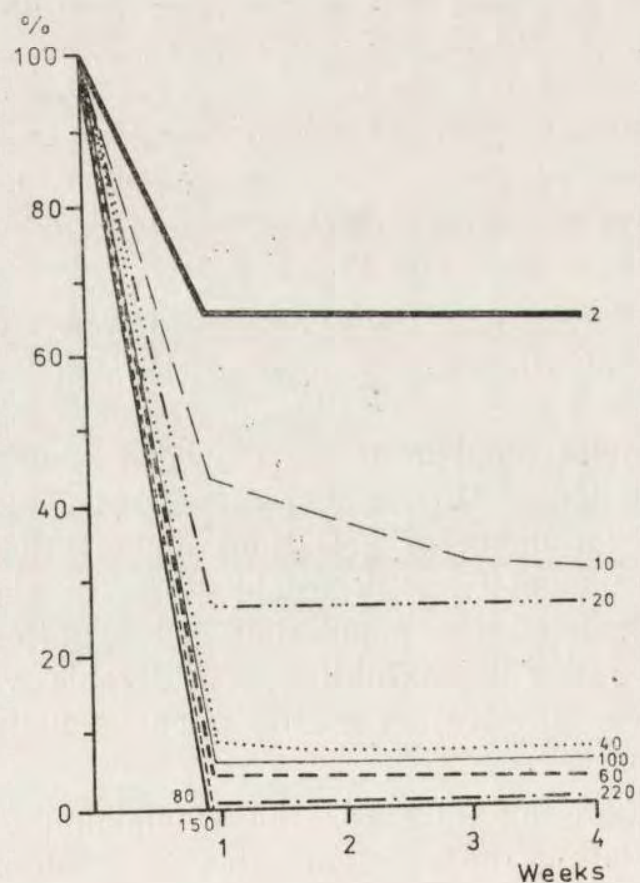

Fig. 3. Survival of young mice in successive weeks of life. Figures by curves indicate the size of the basic stock. 
average values of this rate for populations of different size of basic stock and survival curves plotted for different weeks of life of young individuals in the population (Fig. 3). The survival rate was lowest during the first week of life in all populations. From the first to the fourth week survival curves were maintained at a relatively constant level, and followed a course related to the gradient of basic stock size - the larger this stock, the lower the level of the survival curve. This means that age and the number of adult individuals in a population (for basic stocks up to 60 ) affected the survival rate of young mice. Above 60 individuals the index is close to zero as early as the first week of life for the young mice.

Calculation was made for each population of the percentage of mice, from among those born during the study period, which survived to the age of 4-6 weeks, that is, to the age at which young animals were removed from the population. Investigation was then made to see whether this rate was influenced by the size and density of the basic stock. An increase in the number and density of animals in the basic stock reduced the survival rate of young mice in small populations (Table 4, row 7). In large populations it was not ascertained whether the value of the survival rate changed significantly due to the effect of the factors studied. The analysis of all populations together showed that both increase in the size of the basic stock and its density reduced the survival rate of young mice.

Summing up, it can be said that in small populations an increase in density increased cannibalism and reduced survival up to the age of 4 weeks, and an increase in the number of animals also reduced this latter rate. In large populations an increase in density did not exibit any significant influence on survival rates, while an increase in the number of animals intensified cannibalism and reduced survival in mice up to 4 weeks old.

\section{JUVENILE GROWTH}

Average body weights of mice during the first five weeks of life were calculated, combining mice from populations of indentical density and different size of basic stock in one group. Thus the various groups of populations differed from each other with respect to density. Curves illustrating growth of young individuals were plotted for each group (Fig. 4). The curves are based on the weights of a total of 1924 individuals, the largest group of populations with 596 mice being that with the lowest density ( 3 individuals $/ \mathrm{m}^{2}$ ). An uneven rate of growth was found in this group of populations. Between the second and third week 
of life it was distincly lower then in the remaining weeks. Inhibition of the increase in body weight may be due to the inception of intensive growth of the long bones ( $\mathrm{H} \mathrm{a} \mathrm{m} \mathrm{mond,} \mathrm{1949).} \mathrm{In} \mathrm{populations} \mathrm{with}$ density higher than 3 individuals $/ \mathrm{m}^{2}$ inhibition of growth is not observed, possibly due to the curves plotted representing a smaller number of animals. In the first week growth curves are similar at all densities, but from the second week differences can be observed - the greater the density of individuals in the basic stock, the smaller the average weight (Fig. 4). The size of the basic stock also exerted an influence on the relationship between average weight and density.

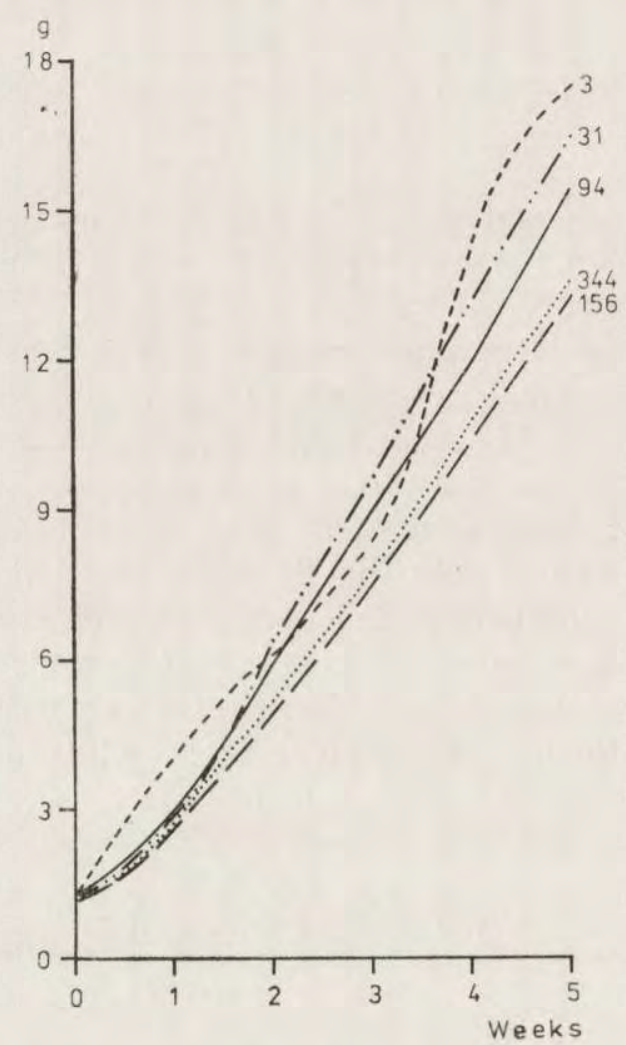

Fig. 4. Curves of individua growth in populations with different density of the basic stock. Figures by curves indicate density $/ \mathrm{m}^{2}$.

Examination was made to determine how increases in size and density of the basic stock affected the average weight of mice at 4 weeks of age, and it was found that there are distinct differences between average body weight in the various populations. On account of the low survival 
rate of mice to the age of 4 weeks, particularly in large populations, statistical analysis was made only for all the populations together. This showed that the average weight of a young individual decreased with an increase in density, while the number of animals in the basic stock did not affect weight (Table 4, row 8). The results obtained confirm Walkowa's (1971) assumption that an increase in the density of adult individuals in a population creates worse conditions for growth of the young individuals.

\section{POPULATION PRODUCTION}

The amount of biomass produced by a population in a given period which is not used to cover maintenance costs of the population itself, was taken as production (Petrusewicz, 1966a, 1967), in other words, the total of increases in body weight of all individuals plus the biomass of newborn mice.

In our studies we estimated total production for each population and distinguished the following elements in it:

(1) Production of mice born (the total body weight of newborn mice).

(2) Production of young individuals up to 4 to 6 weeks old (this is the production of newborn mice plus the sum total of increase in their body weights up to the age of $4-6$ weeks or until the time of their death, if the individual dies at an earlier age than 4-6 weeks).

(3) Production of adult mice (individuals in the basic stock) calculated as the sum total of increase in body weight of all individuals less the sum total of losses in their body weights.

Besides, the total body weight of mice at $4-6$ weeks old which were removed from the populations was distinguished and determined as production removed from the populations.

The value of total production varied greatly. An example of the greatest variation is provided by populations in which the basic stock consisted of 20 individuals and density was $31 \mathrm{mice} / \mathrm{m}^{2}$, where the minimal value of production for the whole study period was $1022 \mathrm{~g}$ and the maximal $3174 \mathrm{~g}$.

The dependence of total production of a population on the size and density of the basic stock was examined. It was found that there was a straight positive relationship between total production and the number of animals in the basic stock, in both small and large populations, and consequently in all the populations analyzed together (Table 4, row 9). The effect of density on production was, however, evident only in the case of small populations - an increase in density reduced production.

Variations in the percentage of total production contributed by the 
three age groups distinguished above were analyzed and their relationships to changes in size and density of the basic stocks were evaluated.

The percentage of biomass production of newborn mice in the total production did not change with increases in the number and density of individuals in the basic stock in small populations (Table 4, row 10). This percentage increased with an increase in the number of mice in large populations, whereas density did not exert any significant effect. The same relationships were found when all populations were analyzed together.

The percentage of biomass production by young mice exhibited considerable variation in different populations. In small populations the minimum was $40 \%$ and the maximum $100 \%$, and in large populations, $71 \%$ and $99 \%$. Variations in this percentage were not, however, affected by variations in either number or density of animals in the basic stock (Table 4, row 11 ).

The value of total production of a population is composed of production of young mice and production due to increase or decrease in biomass of individuals in the basic stock. Thus the value of the percentage formed by production of individuals in the basic stock and the percentages contributed by newborn and young individuals sum to $100 \%$. Despite the fact that production of young mice generally formed the majority of total production in a population, the directions taken by variations in value of these two percentages are directly connected with each other. If therefore none of the factors examined significantly affects the direction of variations in value of the participation of young animals, none of them influence the direction of variations in percentage of production of individuals in the basic stock.

Production of a population provides us with information about the amount of biomass potentially available to other trophic levels (if accessibility is $100 \%$ ). In the present studies biomass produced by a population was obtained by the experimenter by removing individuals from 4-6 weeks old from the population. The biomass of individuals removed from a population of uniform size and density of the basic stock varied. For instance, with stock size of 20 mice and density of 31 individuals $/ \mathrm{m}^{2}$, the minimum value of this biomass was $170 \mathrm{~g}$ and maximum $2440 \mathrm{~g}$, the latter value also being the highest value of biomass removed from the population.

The effects of size and density of the basic stock on the value of biomass obtained from the populations were examined. For small populations it was shown that the value of this biomass was dependent 
on both factors (Table 4, row 12). The value of biomass obtained increased with an increase in size of the basic stock and decreased with an increase in its density. In large populations the factors examined were not found to exert a significant effect on variations in the value of the biomass obtained.

In order to estimate what part of the biomass production was removed from each population, its percentage with respect to total production of the population was calculated. Variations in this percentage due to variations in size and density of the basic stock were then analyzed. In small populations an increase in density reduced the percentage of biomass obtained, while the size of the basic stock did not exert any significant influence (Table 4, row 13). In large populations the factors examined were not shown to affect variations in percentage of biomass removed. Analysis of all populations together showed that both size and density of the basic stock exerted an effect on the amount of biomass removed. Increases in both factors reduced the percentage of biomass removed in the total production.

Individuals born into a population could survive up to the age at which they were removed from the population, could remain in the population in order to compensate for losses in the basic stock or could die before reaching the appropriate age. The biomass of these last animals was lost under the conditions of the experiment. The percentage formed by biomass of mice dying before reaching the age of 4 weeks in the production of young mice was calculated and the effects of size and density of the basic stock on variations in this percentage were examined. In small populations it was found that the percentage of dead biomass increased with an increase of the basic stock, whereas the number of animals was not of significance (Table 4, row 14). In large populations none of the factors examined significantly affected the direction taken by variations in this percentage, but analysis of all populations together showed that both increases in the size of the basic stock and in density increased the percentage formed by dead biomass in the production of young mice.

Summing up, it was found that in small populations total production of the population and exploited biomass increased with an increases in the number of animals. Total production in small populations decreased with an increase in density, as did exploited biomass and its percentage of total production, while the percentage of biomass of dead mice increased in the production of young mice. In large populations total production increased with an increase in the number of animals, as did the percentage formed by production of newborn mice. An increase in density in large populations did not have an; significant 
affect on the production elements analyzed. When all populations are examined together it was found in addition that an increase in the number of animals increased the percentage of total production formed by biomass of dead mice and reduced the percentage of exploited biomass, which was not observed in the analysis made separately for small and large populations.

\section{DISCUSSION}

In studies made up to the present the influences exerted by size and density of a population on its parameters have generally been considered jointly (Anderson, 1961; Crowcroft \& Rowe, 1963; Petrusewicz, 1963, 1966; Walkowa, 1971 and others). This was due to the fact that increases in the number of animals in a captive population simultaneously increased their density.

In the present paper we have tried to ascertain how population parameters are altered by variations in size and density of a population, considering the affect of each of these factors separately. In was found that each of these factors acts in a different way depending on the size of the population. In small populations (up to 20 mice) both the number of animals and their density affect the majority of the above parameters, although they generally had opposite effects. An increase in the number of animals increased production of biomass and other population parameters influencing increased production, while an increase in density reduced these parameters. In large populations (from 40 to 220 individuals) the effects of the number of animals on population parameters were maintained, while density no longer played a significant part as a limiting factor (Fig. 5).

The high fecundity of rodents is an important factor adapting them to the great variety of conditions under which they occur. Some research workers consider fecundity as the chief factor controlling population size (e.g. Strecker \& Emlen, 1955; Crowcroft \& Rowe, 1957), while others consider mortality among young mice as the main factor (Brown, 1953; Southwick, 1955; Petrusewicz, 1963, 1966; W a $1 \mathrm{k}$ ow a, 1971 and others).

The results of the studies presented in this paper indicate that in captive populations of white mice it is mortality rather than natality which must be considered as the chief factor controlling numbers. It is only in small populations that deterioration on living conditions, such as takes place as the result of increases in density, reduces reproduction by prolonging the interval of time between gestations, which reduced 
the number of newborn mice produced by one female during the study period (Table 4, row 4).

An increase in the number of mice did not reduce natality and did not cause a decrease in the number of females taking part in reproduction, contrary to the results obtained by other experimenters (Bailey, 1966; Lloyd \& Christian, 1967; Rainer \& Pe$\mathrm{tr}$ a s, 1967 and others).

\begin{tabular}{|c|c|c|c|c|}
\hline \multirow{2}{*}{\multicolumn{2}{|c|}{$\begin{array}{l}\text { Index } \\
\text { examined }\end{array}$}} & \multicolumn{2}{|c|}{$\begin{array}{l}\text { Populations with } \\
\text { size of the basic } \\
\text { stock }\end{array}$} & \multirow{2}{*}{$\begin{array}{c}\text { All } \\
\text { populations }\end{array}$} \\
\hline & & small & large & \\
\hline \multicolumn{2}{|c|}{$\begin{array}{l}\text { Total } \\
\text { production }\end{array}$} & & & \\
\hline \multicolumn{2}{|c|}{$\begin{array}{l}\text { Biomass } \\
\text { removed }\end{array}$} & & & $\begin{array}{c}\text { not } \\
\text { counted }\end{array}$ \\
\hline \multirow{3}{*}{ 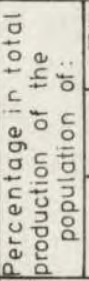 } & $\begin{array}{l}\text { production } \\
\text { by newborn } \\
\text { animals }\end{array}$ & & & \\
\hline & $\begin{array}{l}\text { biomass } \\
\text { removed }\end{array}$ & & & \\
\hline & $\begin{array}{l}\text { dead } \\
\text { biomass }\end{array}$ & & & \\
\hline \multicolumn{2}{|c|}{$\begin{array}{c}\text { Number of newborn } \\
\text { mice in the popula- } \\
\text { tion }\end{array}$} & & & \\
\hline \multicolumn{2}{|c|}{$\begin{array}{l}\text { Number of newborn } \\
\text { mice per female in } \\
\text { basic stock }\end{array}$} & & & \\
\hline \multicolumn{2}{|c|}{ Cannibalism } & & & \\
\hline \multicolumn{2}{|c|}{$\begin{array}{l}\text { Survival of mice } \\
\text { up to the age of } \\
4 \text { weeks }\end{array}$} & & & \\
\hline
\end{tabular}

Fig. 5. Direction of changes in population parameters due to the effect of changes in size (continuous arrow) and density (dotted arrow) of the population. Horizontal line indicates absence of significant relations.

The maximum mortality rate among young mice during the first week of life observed in this present study (Fig. 3) corresponds with the result of other studies (B rown, 1953; Southwick, 1959; Lidicker, 1965; Petrusewicz, 1963, 1966; Lloyd \& Christi a n, 1969). W a lk ow a (1971) considers that mice up to two weeks old from the reserve of the population, responding to disturbances by reducing its size, or increasing »in case of need".

The results of the experiments discussed in this paper show that cannibalism is the chief cause of mortality among newborn mice. It 
increases with an increase in density in small populations and with an increase in the number of mice in large populations (Table 4, row 5).

In previous studies increases in intensity of reciprocal aggressive attitudes between adult individuals, arising as the result of an increase in density, have been considered as the cause of increased mortality (Crowcroft \& Rowe, 1963; Petrusewicz, 1963, 1966; Walk ow a, 1971 and other). Vess ey (1967) increased survival of young individuals by administering tranquilizers to the adult mice. Pool \& M org a n (1971) showed that the number of animals may also reduce survival of young mice, since in large populations the social hierarchy is less stable than in small ones.

The number of animals in a group may play the part of a stress factor, not only in rodent populations. $\mathrm{K} \mathrm{n}$ a p (1970) found that an increase in the size of the group of young pigs, when constant density was maintained, reduced the rate of biomass production. The author explained this by the absence of reciprocal recognition among young pigs in large groups. This assumption is confirmed by the results of Engel man's (1967) experiments, in which he examined the social hierarchy in a flock of hens and found that when the number of birds in a flock exceeded 150 they did not recognize each other.

Maximum population size at which the individuals reciprocally recognize each other was not determined for laboratory mice. Although K a łk owski (1967) showed experimentally that one individual in capable of recognizing at least 18 others by smell, these studies were not made in a population. The fact that alien individuals introduced into a population were attacked by the local animals provides evidence of reciprocal recognition by laboratory mice (A ndrzejewski et al., 1963; W a lk ow a, 1964). The more efficient the sense organs and the greater the memorising capacity, the greater the number of its fellows an animal is able to remember.

The reduction in survival of adult mice of both sexes found in this study with an increase in the number of animals may have been due to a decline in the state of health, manifested in the form of skin infections. Adult males are less resistant than females and young animals are more resistant than adult ones. This is not, however, connected with age but may be due to the shorter time spent by young mice under the influence of the stress factor formed by the large number of animals. The fact that no changes in the skin were observed in adult individuals in small populations, despite the fact that they were of the same age as diseased mice in large populations, leads to this conclusion.

The above visual observations were confirmed by the physiological examination made at the end of the experiment. A decrease in specific 
resistance of males was found with increase in population size above 20 individuals (Rysińska \& Leźnicka, 1972).

Christian (1963), and Christian \& Davis (1964) also found a reduction in the resistance of laboratory mice and explained this by an intensification of social pressures of a stress-forming character, which increased with an increase in density or number of animals (Gartner \& Bonath, 1971). This stress inhibits production of antibodies and may consequently lead to an increase in mortality.

The metabolism of mice in the populations examined in this study was also studied. It was found that an increase in population size raised the metabolic rate of adult mice (basic stock) and reduced that of young mice up to 4 weeks old (M y r c h a, 1975).

The changes in resistance and metabolic rate discussed above point to an intensification of stress with an increase in the number of animals in a population.

Analysis of total production of populations and production of their component elements shows that exploitation of biomass from large populations by a higher trophic level is only favourable when the youngest biomass is removed (newborn mice), since an increase in their size does not affect reproduction, but results in unsuitable conditions for rearing progeny. In small populations conditions exist which permit of obtaining biomass from older individuals (from 4-6 weeks old) and the greatest value can be obtained with a population size of 20 individuals.

The results of studies presented in this paper and their comparison with the results of other authors can be considered from three view points: number of direct contacts between animals, size of the area occupied by a population and number of animals in the population. Despite the mathematical relationship between density, the number of animals and size of area occupied, it would seem that each of these values exerts a different effect on the processes taking place in the population. This is indicated by the studies made on populations of Paramecium (Grębecki \& Petrusewicz, 1963), Tribolium (Peirusewicz et al., 1962), laboratory mice (Petrusewicz \& Tro j a n, 1963), in which a common result was observed - a disproportionate increase as the result of increasing the living area. Different processes take place in populations of each of these species, but attempts at explaining them have been made only in the case of populations of laboratory mice. Relationships and links between components of the population may change with density, size of cage and number of animals 
(Petrusewicz \& Trojan, 1963). An increase in contacts through physiological and behavioural changes leads to changes in population parameters. This effect of variations in density may serve as important control mechanisms in populations living under natural conditions, in which considerable distances often separate the animals, or their contacts are limited by territorial behaviour. In captive populations, on the other hand, (e.g. laboratory mice, domestic animals) in which the living area is sufficiently small for each individual to be able to run through it within a few seconds and territoriality is not manifested $(\mathrm{Trojan}$, 1975), reduction in distance between animals may not increase frequency of contacts but may change their character (Petrusewic z, 1963). It would therefore appear that density is not able to effect significantly frequency of contacts between individuals, as the area in which the populations live in small (in the study populations maximum cage size was $\left.4.8 \mathrm{~m}^{2}\right)$.

If it not possible to explain the significant effect of density on population parameters by frequency of contacts, it is necessary to consider another possibility. Density is the reverse of the living area available per individual. The sum of the living areas of all indiiduals defines the size of the population's living area. If population size is to be maintained at a constant level for a captive population, then to increase density it is necessary to reduce the population's living area. Depending on the size of the area available to the population, the individuals are able to a greater or lesser degree to satisfy their living requirements. This involves deterioration of living conditions for all the individuals in a population, and this is reflected in population parameters.

In populations in which the number of animals exceeds a given threshold value (probably different for each species), in order to maintain the same density as in small populations it is necessary to increase the area in which the animals are kept. In this way a large population has a far larger area at its disposal than a small population on the same density. Owing to the appropriate size of the area individuals are better able to satisfy their living requirements and therefore density ceases to be a factor inhibiting increase in the population's production.

In populations living under natural conditions density is a reflection of the distance between individuals, a change in which increases or reduces the possibility of contacts. In populations kept in a small area, in which contacts take place between the various individuals, density is an index of the size of the area defining the degree to which living needs are satisfied. The results of the present study show that in each populations a third aspect of the question is of significant importance: 
that is, population size and phenomena arising in association with it. Increase in the number of individuals in a population results not only in a quantitative increase in the number of contacts, but also a change in their quality. In populations consisting of a small number of animals the animals are able to remember and recognize their interactions with other individuals, and therefore certain individuals may avoid encounters likely to produce conflicts, if the size of the area permits their doing so. In large populations, on the other hand, the animals are not able to recognize each other (since there are too many of them). Contacts between individuals which do not remember interactions with other individuals, may act as a factor intensifying stress. It may therefore be assumed that a different population affects arise as the result of contacts (even if frequent) between individuals recognizing each other and those in which there is no such recognition.

According to this hypothesis reduction in population production and parameters responsible for this decrease are caused by the living area of the population being too small and failing to satisfy the living requirements of the animals. When the area is sufficiently large to satisfy these requirements, the value of production is determined by the number of contacts between individuals not knowing each other.

Acknowledgements: My thanks are due to doc. dr hab. R. Andrzejewski and $\mathrm{dr} \mathrm{W}$. Walkowa for guidance and advice during the execution of these studies and preparation of the paper, Prof, dr K. Petrusewicz for his valued comments, and the Statistics and Model Construction Section of the Institute of Ecology, Polish Academy of Sciences, for carrying out calculations in connection with regression analysis and mathematical consultation.

\section{REFERENCES}

1. Adamczyk K. \& Walkowa W., 1974: Estimating the number of newborn animals in enclosed populations of laboratory mice. Acta theriol., 19, 16: $247-257$.

2. Allee W. C., Emerson A. E., Park O., Park T. \& Smith K. P., 1949: Principles of animal ecology. W. B. Sanders Philadelphia.

3. Anders on P. K., 1961: Density social structure and nonsocial environment in house mouse populations and implication for regulation numbers. Trans. N. Y. Acad. Sci., 23, 5: 1447-1451.

4. Andrzejewski R., Petrusewicz K. \& Walkowa W., 1963: Absorbtion of newcomers by a population of white mice. Ekol. pol., A, 11: 223-240.

5. Backiel T. \& LeCren E. D., 1967: Some density relationships for fish population parameters. Biol. Basis of Freshwater Fish Production: 261-293.

6. B a il e y E. D., 1966: Social interaction as a population regulating mechanisms in mice. Canad. J. Zool., 44, 6: 1007-1012.

7. Brown R. Z., 1953: Social behaviour reproduction and population changes in the house mouse (Mus musculus L.). Ecol. Monogr., 23: 217-240.

8. Christian J. J., 1963: Endocrine adaptative mechanisms and the physio- 
logie regulation of population growth. [In: "Physiological Mammalogy «, ed. W. V. Mayer \& R. G. Gelder]. Academic Press, 1: 189-353.

9. Christian J. J. \& Davis D. E., 1964: Endocrin's behaviour and population. Science, 146: 1550-1560.

10. Crowcroft P. \& Rowe F. P., 1957: The growth of confined colonies of the wild house mouse (Mus musculus L.). Proc. zool. Soc., 129: 359-370.

11. Crowcroft P. \& Rowe P. P., 1963: Social organization and territorial behaviour in the wild house mouse (Mus musculus L.). Proc. zool. Soc., Lond. 140: $517-531$.

12. E 1 and E., 1964: Statystyka matematyczna w zastosowaniu do doświadczalnictwa rolniczego. Państw. Wyd. Nauk.: 437-457. Warszawa.

13. Engelma n C., 1967: Ergebnisse der Verhaltensforschung an Geflugel. 1. Die naturlichen Verhaltensweissen. Tierzucht, 21, 8: 410-412.

14. Gärtner K. \& Bonath K., 1971: Der Einflus der Gruppengrosse auf den Kortäcosterogehalt der Nebennieren und des Serums mänlicher Mäuse und Ratten. Endocrinologie, 58: 129-139.

15. Grębecki A. \& Petrusewicz K., 1963: Density and size of medium in populations of Paramecium caudatum. Ekol, pol., A, 11: 589-600.

16. H ammond J., 1946: Farm animals. Edward Arnold Publ.: 1-266. London.

17. Hansen R. S. \& Becker W. A., 1960: Feeding space, density and growth of young chickens. Poultry Sci., 39: 654-661.

18. Kałkowski W., 1967: Olfactory bases of social orientation in the white mouse. Folia biol. 15: 69-87. Kraków.

19. Knap J. \& Kaspar F., 1969: Vliv počtu na přirustku a spostřebu krmiv, Živocis. Vyr., 14, 9: 683-668.

20. Knap J., 1970: Etologia prasat ve vztahu $\mathrm{k}$ užitkovosti, při rüźnem počtu prasat v kotci. Ved. Pr. vyz. Ust. Chov. Prasat Kostelci, 3: 149-157.

21. Lidicker W. Z., 1965: Comparative study of density regulation in confined populations of four species of rodents. Res. Popul. Ecol., 7: 57-72.

22. Lloyd J. A. \& Christian J. J., 1967: Relationship of activity and agression to density in two confined population of house mice (Mus musculus I.). J. Mammal., 48: 262-269.

23. Lloyd J. A. \& Christian J. J., 1969: Reproductive activity of individual females in three experimental freely growing populations of house mice (Mus musculus L.). J. Mammal., 50: 49-59.

24. Łomnicki A., 1972: Planning of deer population management by non-linear programming. Acta theriol., 17: 137-150.

25. Mazanowski A., 1972: Obsada kur niosek a produkcja jaj. Drobiarstwo, 20, 4: $9-10$.

26. Myrcha A., 1975: Comparison of the bioenergetics of an experimental and individual laboratory mice. Acta theriol., 20, 16: 175-226.

27. Petrusewicz K., 1963: Population growth induced by disturbance in the ecological structure of the population. Ekol. pol., A, 11: 87-125.

22. Petrusewicz K., 1966: Dynamics, organisation and ecological structure of population. Ekol. pol., A, 14: 413-436.

29. Petrusewicz K., 1966a: Niektóre pojęcia w badaniach produktywności wtórnej. Kosmos, 2: $581-599$.

30. Petrusewicz K., 1967: Concepts in studies on the secondary productivity of terrestial ecosystems. [In: „Secondary productivity of terrestial ecosystems ", ed. K. Petrusewicz], 1: 17-49, Polish Sci., Publisher, Warszawa-Kraków. 
31. Petrusewicz K., Prus T. \& Rudzka H., 1963: Density and size medium in populations of Tribolium. Ekol, pol., A, 11: 603-608.

32. Petrusewicz K. \& Trojan P., 1963: The influents of size of the cage on the numbers and density of a selfranging population of white mice. Ekol. pol., A, 11: $611-614$.

33. Pool T. B. \& Morgan H. D., 1973: Differences in aggressive behaviour between male mice (Mus musculus L.) in colonies of different sizes. Animal Behaviour, 21: 788-795.

34. Reimer J. D. \& Petras M. L., 1967: Breeding structure of the house mouse, Mus musculus, in a population cage. J. Mammal., 48: 88-99.

35. Rysińska A. \& Leźnicka B., 1972: Badania wpływu zagęszczenia populacji białych myszy na liczbę komórek śledziony wytwarzających przeciwciała. Roczn. Wojsk. Inst. Hig. i Epid., 11, 1-2: 55-60.

36. Southwick C. H., 1955: Regulatory mechanisms of house mouse population: social behaviour affecting litter survival. Ecology, 36: 627-634.

37. Strecker R. L. \& Emlen J. T. Jr., 1953: Regulatory mechanisms in house mouse populations: the effect of limited food supply on a confined population. Ecology, 34: 375-385.

38. Trojan P., 1975: Ekologia ogólna. Państw. Wyd. Nauk.: 1-418, Warszawa.

39. Vessey S., 1967: Effects of chlorpromasine on aggression in laboratory populations of wild house mice. Ecology, 48: 367-376.

40. W a lkowa W., 1964: Rate of absorbtion of newcomers by a confined white mouse population. Ekol. pol., A, 12: 325-335.

41. Walkowa W., 1971: The effect of exploitation on the productivity of laboratory mouse populations. Acta theriol., 16, 295-328.

42. W o ln y P., 1962: Wpływ gęstości obsad na wzrost i stopień przeżycia narybku karpia. Roczn. Nauk Roln., 81, B, 2, 5: 170-188.

Accepted, May 5, 1977.

Krystyna ADAMCZYK

\section{WPEYW WIELKOSCI I ZAGESZCZENIA POPULACJI MYSZY LABORATORYJNYCH NA PARAMETRY OKRESLAJĄCE JEJ PRODUKCJE}

\section{Streszczenie}

Zbadano wpływ liczby i zagęszczenia zwierząt dorosłych $w$ populacji na produkcję, przeżywalność, rozród, przyrosty ciężarów ciała. Badania przeprowadzono na 68 populacjach myszy laboratoryjnych (Mus musculus Linnaeus, 1758). Wyjściową liczbę osobników w wieku około 3 miesięcy ustawiono w gradiencie od 2 do 220 myszy przy równoczesnym wzroście zagęszczenia od 3 do 344 osobników/m² (eksperyment I) oraz przy tym samym gradiencie liczby zwierząt, lecz przy zachowaniu stałego zagęszczenia, innego w każdej serii (eksperyment II, Tabela 1). Wyjściową liczbę myszy utrzymywano na stałym poziomie w pięcio- 
miesięcznym okresie badań, przez usuwanie osobników młodych w wieku 4-6 tygodni oraz przez pozostawienie zwierząt młodych w miejsce padłych osobników dorosłych.

Analizę wpływu badanych czynników na wskaźniki populacyjne przeprowadzono metodą regresji wielokrotnej prostoliniowej. Zwierzęta dojrzałe płciowo, stanowiące bazę populacji nazwano stadem podstawowym.

Wyróżniono dwie grupy populacji różniące się wielkością stada podstawowego: małe od 2 do 20 myszy i duże od 40 do 220 myszy. Stwierdzono, że w populacjach małych zarówno liczba zwierząt jak i ich zagęszczenie mają istotny wplyw na większość badanych wskaźników, natomiast $\mathrm{w}$ populacjach dużych tylko wpływ liczby myszy jest istotny (Tabela 4, Ryc. 5), Ze wzrostem wielkości populacji zwiększa się liczba noworodków hamowana wzrostem zagęszczenia w populacjach małych, które zmniejsza częstosć zachodzenia samic w ciążę (Tabela 4, szereg 4). Kanibalizm zwiększa się ze wzrostem zagęszczenia w populacjach małych i ze wzrostem liczby myszy w populacjach dużych (Tabela 4, szereg 5). Przeżywalność myszy młodych jest najmniejsza w pierwszym tygodniu życia i zmniejsza się ze wzrostem wielkości stada podstawowego (Ryc. 3). Wzrost liczby zwierząt i zagęszczenia obniża przeżywalność myszy do wieku 4 tygodni ale tylko w populacjach małych (Tabela 4, szereg 7). W populacjach dużych przeżywalność myszy do tego wieku jest bardzo niska i nie zmienia się kierunkowo pod wpływem badanych czynników. Przeżywalność osobników stada podstawowego obu płci maleje ze wzrostem liczby myszy (Tabela 4, szereg 1, 2). Wzrost liczby zwierząt obniża ich odporność na choroby (Ryc. 1).

Produkcja ogólna populacji zwiększa się ze wzrostem liczby zwierząt w obu grupach populacji a zagęszczenie jest czynnikiem hamującym ale tylko w populacjach małych (Tabela 4, szereg 9). W populacjach dużych wzrost ten spowodowany jest głównie zwiększeniem biomasy noworodków a w populacjach malych również przez przyrosty ciężarów ciała. Biomasa myszy wyjętych z populacji zwiększa się ze wzrostem liczby zwierząt w stadzie podstawowym do 20 osobników z tym, że hamowana jest wzrostem zagęszczenia (Tabela 4, szereg 12). W populacjach dużych biomasa ta wykazuje wahania ale nie zmieniające się kierunkowo pod wpływem nasilania się badanych czynników.

W pracy dyskutuje się wpływ liczby zwierząt $w$ populacji, zagęszezenia i zajmowanej powierzchni na przebieg procesów populacyjnych $w$ warunkach hodowli zwierząt. 